\title{
Radial aplasia and chromosome 22q11 deletion
}

Maria Cristina Digilio, Aldo Giannotti, Bruno Marino, Anna Maria Guadagni, Marcello Orzalesi, Bruno Dallapiccola

\begin{abstract}
We report on a neonate with deletion $22 q 11$ (del22q11) presenting with facial dysmorphism, ocular coloboma, congenital heart defect, urogenital malformations, and unilateral radial aplasia. This malformation complex includes features frequently occurring in velocardiofacial syndrome as well as findings described in the CHARGE and VACTERL associations. To our knowledge, the present case is the first report of radial aplasia in del22q11. This observation further supports and extends the clinical variability of del22q11.

(F Med Genet 1997;34:942-944)
\end{abstract}

Keywords: upper limb anomaly; radial anomaly; deletion 22q11; velocardiofacial syndrome

Deletion of chromosome 22q11 (del22q11) is a major cause of DiGeorge, ${ }^{1}$ velocardiofacial, ${ }^{1-3}$ conotruncal anomaly face, ${ }^{4}$ and Opitz ${ }^{5}$ syndromes. The acronym CATCH22 has been proposed to encompass the major clinical manifestations occurring in this disorder $(\mathrm{C}=$ cardiac defect, $\mathrm{A}=$ abnormal face,
$\mathrm{T}=$ thymic hypoplasia, $\mathrm{C}=\mathrm{cleft}$ palate, $22=22 \mathrm{q} 11$ deletion), ${ }^{6}$ but the deletion spectrum has been progressively widened to include more than 100 symptoms. ${ }^{7-14}$ Upper limb malformations have rarely been described in these patients. They include polydactyly, syndactyly, camptodactyly, thumb anomalies, and lobster claw deformity. ${ }^{6-15}$

We have observed a neonate with del22q11 presenting with a malformation complex characterised by facial dysmorphism, ocular colobomata, congenital heart defect, urogenital malformations, and unilateral radial aplasia. To our knowledge, radial aplasia has never been reported in association with del22q11.

\section{Case report}

The proband, a male, is the first child of healthy, non-consanguineous parents. The mother was 29 years old at the birth and the father 41 . The baby was born by vaginal delivery at term after an uneventful pregnancy. Birth weight was $2800 \mathrm{~g}$, length $49 \mathrm{~cm}$, and head circumference $33.5 \mathrm{~cm}$. Apgar scores were 7 and 9 at one and five minutes. Clinical examination showed horizontal palpebral fissures, flat nasal bridge, epicanthic folds,

\author{
Departments of \\ Medical Genetics, \\ Paediatric Cardiology, \\ and Neonatology, \\ Bambino Gesù \\ Hospital, Rome, Italy \\ M C Digilio \\ A Giannotti \\ B Marino \\ A M Guadagni \\ M Orzalesi
}

Department of Human Genetics, University of Tor Vergata, Rome, and CSS Hospital, San Giovanni Rotondo, Italy

B Dallapiccola

Correspondence to: Dr Giannotti.

Received 15 January 1997 Revised version accepted for publication 21 March 1997
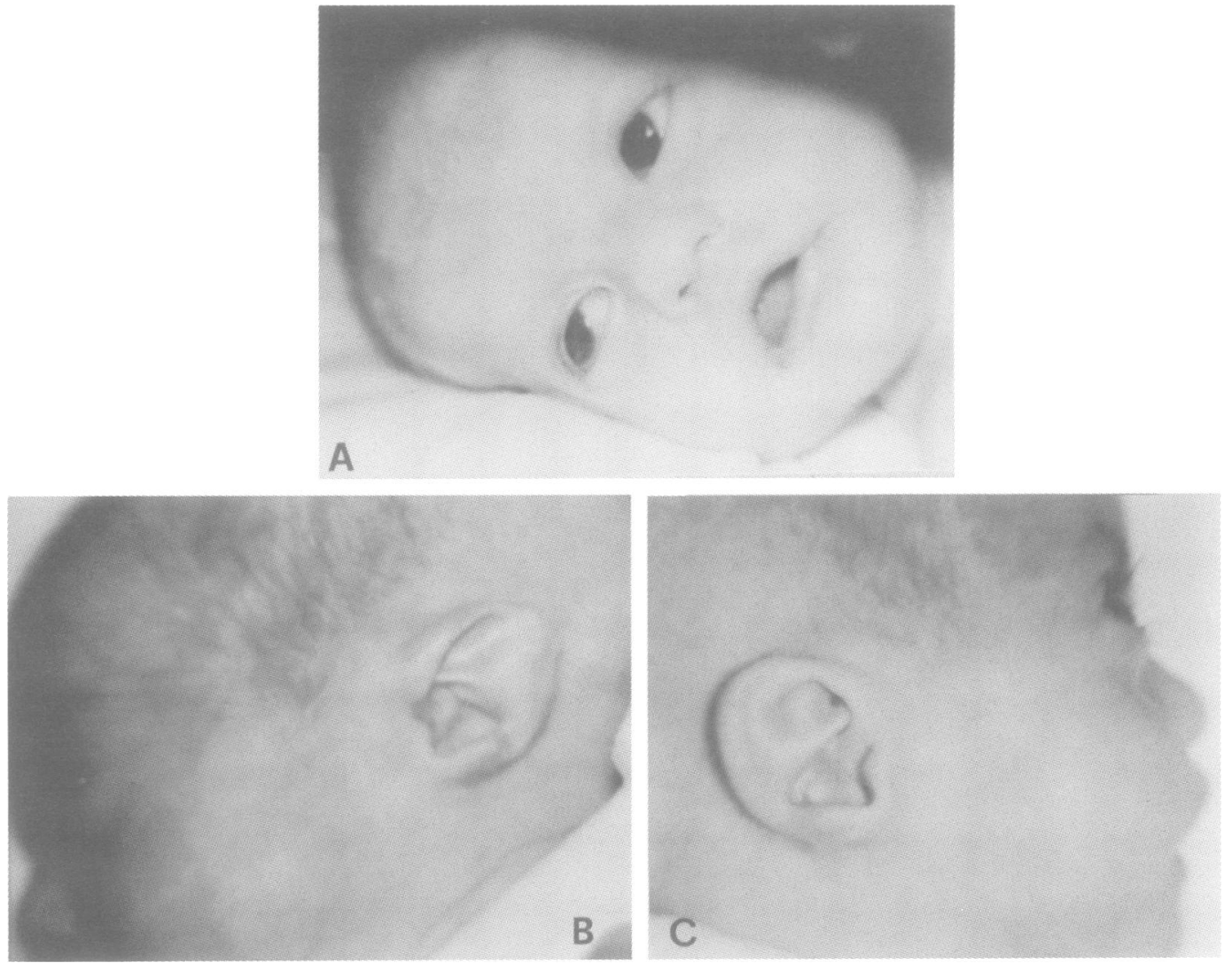

Figure 1 Front $(A)$ and lateral $(B, C)$ views of the patient. (Photographs reproduced with permission.) 
hypoplastic left nostril, unilateral choanal stenosis, flat philtrum, thin upper lip, downturned corners of the mouth, a high palate, and circular, flat, and retroverted dysmorphic ears (fig 1). The genitalia were hypoplastic with a small penis and bilateral undescended testes. The left arm was short with an absent radius and hypoplastic ulna. The left hand was deviated at the wrist, with a hypoplastic first ray, ulnar deviation of the second finger, and camptodactyly of the third and fourth fingers. $X$ ray examination of the left arm and hand (fig 2) showed an absent radius, hypoplastic ulna, short first metacarpal bone, hypoplastic phalanges of the first finger, and clinodactyly of the second finger. No additional skeletal abnormalities were detected on total body examination. Cerebral CT scan was unremarkable. An ophthalmological examination disclosed bilateral retinal colobomata. Fibrolaryngoscopy showed anterior laryngomalacia. A normal thymic shadow was detected on chest $x$ ray. Chest $x$ ray with barium swallow and echocardiography showed double aortic arch, which was repaired at 40 days of age. Renal ultrasonography showed a slight left pelvic ectasia. Transient hypocalcaemia $(7.7 \mathrm{mg} / \mathrm{dl})$ was detected on the second day of life. T lymphocyte numbers were slightly below the normal range.

Standard and high resolution chromosome analysis of peripheral blood lymphocytes disclosed a normal male karyotype. Fluorescent in

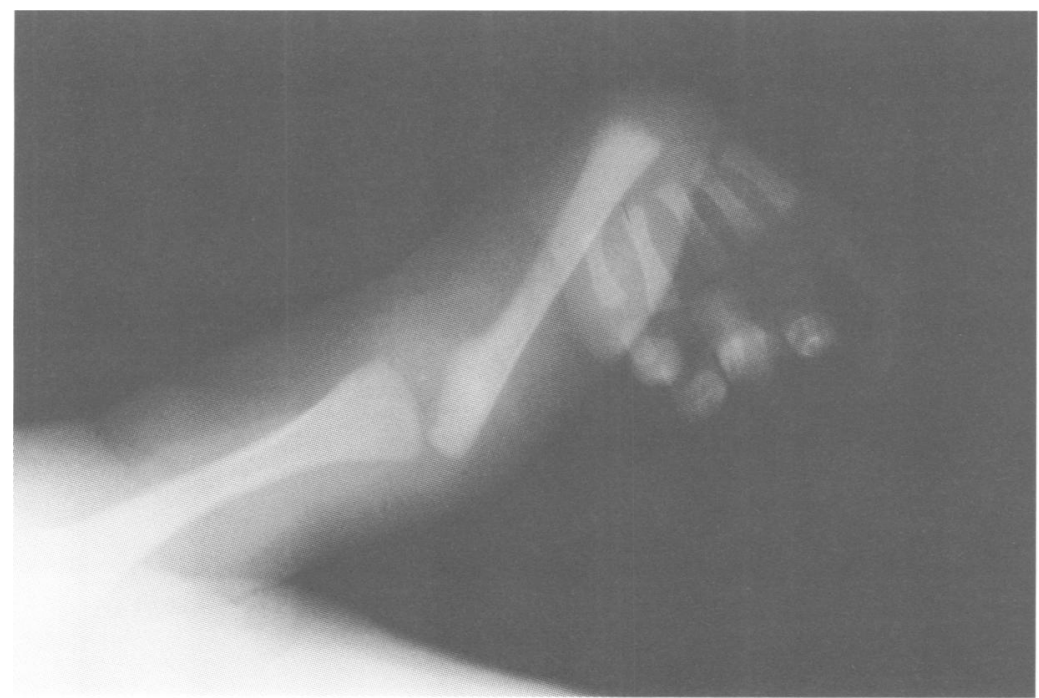

Figure $2 X$ ray examination of the left arm of the patient showing radial aplasia.

Table 1 Clinical manifestations of our patient compared with cardinal features of velocardiofacial syndrome (VCF), DiGeorge syndrome (DG),CHARGE, and VACTERL associations

\begin{tabular}{|c|c|c|c|c|}
\hline Clinical feature & Present case & $V C F / D G$ & $C H A R G E$ & VACTERL \\
\hline $\begin{array}{l}\text { Facial dysmorphism (quite distinct } \\
\text { in different disorders) }\end{array}$ & + & + & + & + \\
\hline Ocular colobomata & + & + & + & - \\
\hline Choanal stenosis & + & - & + & - \\
\hline Cleft palate & - & + & + & - \\
\hline Cardiac defect & + & + & + & + \\
\hline Tracheo-oesophageal fistula & - & - & - & + \\
\hline Vertebral defects & - & + & - & + \\
\hline Radial ray defects & + & + & - & + \\
\hline Renal anomalies & + & + & + & + \\
\hline Genital defects & + & + & + & + \\
\hline Hypocalcaemia & + & + & + & - \\
\hline Thymic hypoplasia & - & + & - & - \\
\hline
\end{tabular}

situ hybridisation (FISH) analysis with Sc11.1, ${ }^{19} \operatorname{co} 23,{ }^{20}$ and D22S75 and D22S39 (control, ONCOR) probes showed 22q11.2 hemizygosity.

\section{Discussion}

Upper limb malformations described in patients with the CATCH22 phenotype include preaxial and postaxial polydactyly, syndactyly, camptodactyly, club hands, thumb hypoplasia, and lobster claw deformity. ${ }^{6-18}$ To our knowledge, the present case is the first report of radial aplasia in del22q11, although other types of radial ray defects have been found previously. ${ }^{15}$ In addition, it is interesting to note the unilateral nature of the limb defect in the present case. The malformation complex presented by our patient includes findings frequently occurring in velocardiofacial syndrome, such as facial dysmorphism, high palate, neonatal hypocalcaemia, aortic arch defect, and urogenital anomalies ${ }^{21}$ (table 1). Ocular coloboma has also been reported in velocardiofacial syndrome. ${ }^{22}$ The association of this defect and choanal stenosis is suggestive of the CHARGE association ${ }^{23}$ (table 1). The clinical overlap between velocardiofacial syndrome and CHARGE association has been noted previously. ${ }^{24}$ Del22q11 has been reported in a few CHARGE patients, ${ }^{25}$ but extensive molecular analyses have failed to show this hemizygosity. ${ }^{26} \mathrm{~A}$ clinical diagnosis of VACTERL association was suggested in our patient because of the combination of aortic arch defect and radial aplasia, ${ }^{27}$ but was not supported by the absence of vertebral, anal, and tracheoesophageal anomalies (table 1).

The present observation further supports and extends the clinical variability of $\operatorname{del} 22 \mathrm{q} 11$, and adds radial aplasia to the list of symptoms associated with CATCH22 patients.

1 Driscoll DA, Salvin J, Sellinger B, et al. Prevalence of 22q11 microdeletions in DiGeorge and velocardiofacial syndromes: implications for genetic counselling and prenatal diagnosis. F Med Genet 1993;30:813-17.

2 Driscoll DA, Spinner NB, Budarf ML, et al. Deletions and microdeletions of 22q11.2 in velo-cardio-facial syndrome. Am $\mathcal{F}$ Med Genet 1992;44:261-8.

3 Kelly D, Goldberg R, Wilson D, et al. Confirmation that the velo-cardio-facial syndrome is associated with haploinsufficiency of genes at chromosome 22q11. Am $\mathcal{F} \mathrm{Med}$ Genet 1993;45:308-12.

4 Matsuoka R, Takao A, Kimura M, et al. Confirmation that the conotruncal anomaly face syndrome is associated with a deletion within 22q11.2. Am ₹ Med Genet 1994;53.285-9.

5 Robin NH, Opitz JM, Muenke M Opitz G/BBB s3:285-9. obin NH, Opitz clinical comparisons of families linked to $\mathrm{Xp} 22$ and $22 \mathrm{q}$ and a review of the literature. Am $f$ Med Genet

6 Wilson DI, Burn J, Scambler P, Goodship J. DiGeorge syndrome: part of CATCH 22. ₹ Med Genet 1993;30:852syndrome: part of CATCH 22. F Med Genet 1993;30:852

7 Giannotti A, Digilio MC, Marino B, Mingarelli R, Dallapiccola $B$. Cayler cardiofacial syndrome and del22q11: part of the CATCH22 phenotype. Am $\mathcal{F}$ Med Genet 1994;53 303-4.

8 Nickel RE, Pillers DAM, Markens M, et al. Velo-cardiofacial syndrome and DiGeorge sequence with meningomyelocele and deletions of the 22q11 region. $\mathrm{Am} \mathrm{F}$ Med Genet 1994;52:445-9.

9 Chow EWC, Bassett AS, Weksberg R. Velo-cardio-facial syndrome and psychotic disorders: implication for psychiatric genetics. Am ₹ Med Genet 1994;54:107-12.

10 Mitnick RJ, Bello JA, Shprintzen RJ. Brain anomalies in velo-cardio-facial syndrome. Am ₹ Med Genet 1994;54:1006.

11 Lynch DR, McDonald-McGinn DM, Zackai EH, et al Cerebellar atrophy in a patient with velocardiofacial syndrome. $\mathcal{f M e d}$ Genet 1995;32:561-3.

12 Devriendt K, Swillen A, Fryns JP, Proesmans W, Gewillig $M$. Renal and urological tract malformations caused by a 22q11 deletion. 7 Med Genet 1996;33:349-52. 
13 Rasmussen SA, Williams CA, Ayoud EM, et al. Juvenile rheumatoid arthritis in velo-cardio-facial syndrome. Coincidence or unusual complication? $A m \mathcal{F}$ Med Genet 1996;64:546-50.

14 Shprintzen RJ, Shanske A, Marion R, Goldberg R. The expansive phenotype of velo-cardio-facial syndrome: a review of 206 cases. Am ₹ Hum Genet Suppl 1996;59:A20.

15 Cormier-Daire V, Iserin L, Théophile D, et al. Upper limb malformations in DiGeorge syndrome. Am $\mathcal{f}$ Med Genet 1995;56:39-41.

16 Shalev SA, Dar H, Barel H, Borochowitz Z. Upper limb malformations in ch 17 Ming JE, McDonald-McGinn DM, Megerian TE, et al. f Hum Genet Suppl 1996;59:A354.

18 Prasad C, Quackenbush EJ, Whiteman D, Korf B. Limb anomalies in DiGeorge and CHARGE syndromes. Am $\mathcal{F}$ Med Genet 1997;68:179-81.

19 Halford S, Lindsay E, Nayudu M, Caraj AH, Baldini A, Scambler PJ. Low-copy-number repeat sequences flank the DiGeorge-velo-cardio-facial syndrome loci at 22q11. Hum Mol Genet 1993;2:191-6.

20 Pizzuti A, Novelli G, Ratti A, et al. UFD1L, a developmentally expressed ubiquitination gene, is deleted in CATCH 22 syndrome. Hum Mol Genet 1997;6:259-65.
21 Goldberg R, Motzkin B, Marion R, Scambler PJ, Shprintzen RJ. Velo-cardio-facial syndrome: a review of 120 patients. Am $\mathcal{F}$ Med Genet 1993;45:313-19.

22 Mansour AM, Goldberg RB, Wang FM, Shprintzen RJ. Ocular findings in the velo-cardio-facial syndrome. $f$ Pediatr Ophthalmol Strab 1987;24:263-6.

23 Pagon RA, Graham JM, Zonana J, Yong SL. Coloboma, congenital heart disease, and choanal atresia with multiple anomalies: CHARGE association. I Pediatr 1981;99:223-7

24 Pagon RA. Velo-cardio-facial syndrome vs CHARGE "association". Am ₹ Med Genet 1987;28:751-8.

25 Emanuel BS, Budarf ML, Sellinger B, Goldmuntz E, Driscoll DA. Detection of microdeletions of $22 \mathrm{q} 11.2$ with fluorescence in situ hybridization (FISH): diagnosis of DiGeorge syndrome (DGS), velo-cardiodiagnosis of DiGeorge sy CHARGE association and facial (VCF) syndrome, CHARGE association and conotruncal

26 Tellier AL, Théophile D, Bonnet D. CHARGE association: report of 47 cases with genotypic analysis of chromosomes $7 \mathrm{q} 36$ and 22q11. Am f Hum Genet Suppl 1996;59:A20.

27 Khoury MJ, Cordero JF, Greenberg F. A population study of the VACTERL association: evidence for its etiologic heterogeneity. Pediatrics 1983;71:915-20. 